\title{
Knowledge management: a roadmap for innovation in SMEs' sector of Azad Jammu \& Kashmir
}

\author{
Iftikhar Hussain ${ }^{1 *}$, Amber Qurashi $^{2}$, Ghulam Mujtaba ${ }^{3}$, Muhammad Arfaq Waseem $^{4}$ and Zafar Iqbal $^{3}$
}

\author{
* Correspondence: iftikhar_raja@live. \\ com \\ ${ }^{1}$ Faculty of Administrative Sciences \\ Kotli, University of Kotli Azad \\ Jammu \& Kashmir, Kotli, Pakistan \\ Full list of author information is \\ available at the end of the article
}

\begin{abstract}
In this empirical study, we have examined the impact of knowledge management on organizational innovation capacity. Ultimate objective of existing research was to explore the role of knowledge management in encouraging innovation capacity in SMEs. Furthermore, this study also described role of knowledge management process to enhance knowledge repositories of SMEs. In order to understand knowledge management-innovation relationship, we collected data from SMEs across Azad Jammu and Kashmir. It was found that knowledge identification/creation, knowledge collection, knowledge organizing, knowledge dissemination, and knowledge application have positive and significant impact on innovation capacity of the SMEs in AJ\&K. Implications of the study were also discussed.
\end{abstract}

Keywords: SMEs, Managers, Knowledge management, Innovation, Knowledge organizing, Knowledge creation, Knowledge dissemination, Knowledge application

\section{Introduction}

Knowledge Management (KM) is creation of knowledge, followed by knowledge organization, knowledge sharing, disseminating knowledge, knowledge application and use (Bhatt, 2001). KM is noteworthy factor of success for firms and a significant precursor for innovation (Bennett \& Gabriel, 1999; Carneiro, 2000; Darroch \& MacNaughton, 2002; Lin \& Lee, 2005 Chilton \& Bloodgood, 2010) and innovation is milestone of each firm (Carneiro, 2000; Plessis, 2007; Dilk et al., 2008). Nowadays, numerous firms and businesses deem that knowledge is mainly imperative affluence of their firms but practically they do not depend on it. Most central rational is that firms typically do not recognize that in what way they exploit knowledge. Though, there exists numerous models and approaches in KM; models efficacy relies on situations of organizations (Abtahi \& Salavati, 2007).

In spite of this, there are number of empirical studies have been conducted on KM as innovation precursor (Plessis, 2007; Chilton \& Bloodgood, 2010), however, it is tricky to explore occupations that scrutinize empirical connection between constructs. Plessis (2007) outlined innovation as configuration of novel knowledge that assists businesses to create internal business procedures and arrangement more refined that create market suitable services and products. However, innovation does not come easy

(c) The Author(s). 2019 Open Access This article is distributed under the terms of the Creative Commons Attribution 4.0 International License (http://creativecommons.org/licenses/by/4.0/), which permits unrestricted use, distribution, and reproduction in any medium, provided you give appropriate credit to the original author(s) and the source, provide a link to the Creative Commons license, and indicate if changes were made. 
and KM is a significant contributor so far (e.g. Carneiro, 2000; Darroch and MacNaughton, 2002; Goh, 2005; Plessis, 2007; Chilton \& Bloodgood, 2010).

The field of KM is at its maturity (Abtahi \& Salavati, 2007) and researchers have found that SMEs can benefit from KM strategies to innovate for competitive sustainability. The KM concepts, principles and practices have much to offer to the SME sector where scare resources, market agility, closeness to the customers and fewer layers are important (Darroch and MacNaughton, 2002). Improved KM can be really important in all these areas and can become a source of innovation, creativity and competitiveness in SME sector. Although much has been written on SMEs in knowledge management and innovation perspective (Beesley \& Cooper, 2008; Hussain et al., 2010), however, only little has been explored to study SMEs sector in AJ\&K (Hussain et al., 2010) and this study intends to address the existing knowledge gap.

Further, it has also been revealed that little attention has been paid to uncover the knowedge sharing practices of SMEs (Chen et al., 2016; Ferraris et al., 2017; Scuotto et al., 2017; Tether \& Tajar, 2008; Vrontis et al., 2017) and more importantly, a little attention has been paid to discover informal knowledge sharing among SMEs (Bonte \& Keilbach, 2005). Newly established SMEs are facing immense competitive pressure and therefore, knowledge creation and knowledge sharing is inevitable for such SMEs to compete in ever changing environment (Damanpour \& Aravind, 2012; Kim \& Lui, 2015).

Different firms adopt various KM practices to build up novel capabilities, so that they can ensure the progress towards superior performance (Hussain et al., 2010). However, some SMEs are still following traditional business models thereby compromising on change and innovation. The environmental adaptability of the SMEs can enable them to embrace technological changes to remain competitive (Gloet \& Terziovski, 2004).

This research aims to examine the implementation of different knowledge management processes that can be vital to innovative organizational capabilities in SMEs sector. Adopting and implementing knowledge processes can support SMEs' owners and managers to realize the innovation, competitiveness and organizational performance. In this regard, present research adds to the literature on KM and innovation in SMEs by measuring the association between KM processes and organizational innovation in the SMEs context. To the best of our understanding and knowledge, only limited attention has been paid in extant literature and no studies have been found particularly addressing the underlying issues of innovation in AJ\&K. Therefore, focus of existing study was to explore the role of KM factors in bringing innovation in SMEs sector of AJ\&K. The central goals of this investigative study are as under:

In summary, our study aimed to explore (1) the role of KM factors in increasing innovation capacity of SMEs' in AJ\&K and (2) to investigate which KM processes are relatively more significant in shaping innovation capacity of the SMEs in AJ\&K.

\section{Literature review}

\section{Knowledge \& KM}

Davenport and Prusak (2000) describe knowledge like: fluids combination of bounded knowledge, appropriate information, values, and knowledgeable imminent that offers support intended for estimating and integrating novel information and experience. 
Within firms, it frequently turns out to be entrenched not merely in repositories or documents, but also in organizational schedules, procedures, performs and customs.

KM is a multidisciplinary field of study which covers various grounds. Knowledge is an important ingredient for many jobs now a days and sustainability of the businesses is heavily dependent on knowledge. Gloet \& Terziovski (2004) described KM as admittance and formalization to knowledge, experience and proficiency that develop novel potentials, facilitate advanced performance and inspire innovation along with increase in customer value. Previous research have also explained KM under the expression of an umbrella on behalf of range of interlinking expressions. For instance, creation of knowledge, valuation and metrics of knowledge, mapping and indexing of knowledge, transport of knowledge, storage, distribution and sharing of knowledge. Definitions of $\mathrm{KM}$ are different based on reason for what purpose they're proposed (Quintas et al., 1997; Greiner et al., 2007). Within other expressions, "KM might be described as an instrument that supports a firm's strategic plan and its purpose" (Dove, 1999).

\section{Innovation}

Innovation has been defined in many distinct ways, however, according to (Goh, 2005) innovation is an intentional change in the existing products, services, ideas and operations new to the end user or unit of adoption. Creativity and innovation has become imperative for the survival in the competitive markets and firms in established industries investing heavily in R\&D to stay competitive (Hayes et al., 2005). For most SMEs, to innovate constantly is the only remedy for survival. Previous research have shown the significant contribution of innovation and innovative strategies on market share and customer satisfaction (Chen \& Huang, 2007). Therefore, it can be argued that innovation, if explored and exploited carefully can yield optimal benefits for SMEs also.

\section{Knowledge management process}

Knowledge management is associated with knowledge development, regeneration, and exploitation to gain and maintain competitive advantage (Bhatt, 2000; Demarest, 1997; McCampbell et al., 1999; Soliman \& Spooner, 2000; Wiig, 1997a, b). The researchers have described two measurements related to KM: upshots and properties. Three upshots are knowledge creation, retention and transfer. Three possessions of circumstance where KM seems accurate are components properties (e.g. an individual, a group, or an organization), relationships belongings among components (how components are associated among each other to effortless relocation of knowledge), and properties of knowledge itself (private vs. public, tacit vs. explicit etc.) (Argote, McEvily \& Reagans, 2003).

\section{Knowledge creation}

The procedure of attaining novel concepts and novel considerate "by conquering entity boundaries and limitations obliged by in a sequence and precedent learning" is called knowledge creation (Saenz, Aramburu \& Rivera, 2009). Previous researchers described that when discussing directorial knowledge creation, it is all about in which way employee knowledge is linked with certain organization. Multidimensional and dynamic practice of knowledge is the creation of knowledge. Knowledge creation in organization 
is capability of a firm to generate knowledge, mingle this in certain firm, services, products and schemes (Nonaka \& Takeushi, 1995). Knowledge sharing is subject to inquisitiveness of the recipient/knowledge seeker and knowledge inquiry is what KSA (Knowledge, skills and abilities) of human capital is needed to endorse creation of knowledge and in which way they could be different for generalists along with specialists. Bhatt (2001) described that novel creation of knowledge might not essentially establish from graze; it could be constructed upon accessible capabilities. Therefore, it is hypothesized that:

\section{$\boldsymbol{H}_{1}$ : Knowledge identification/creation has positive and significant impact on} innovation capacity of SMEs.

\section{Knowledge collection}

An employee could accumulate rational capital through communicating with other workers (Davenport \& Prusik, 1998). The most significant practice is knowledge creation and employees can distribute it by sharing knowledge. According to Park (2006), sharing of knowledge is noteworthy part of KM. Within any firm, effectual expansion of practices of sharing of knowledge will alter performance and outlook of workers in the direction of eagerness to contribute along with to gather knowledge (Van den Hooff \& Van Weenen, 2004). Park (2006) described that firms must gather knowledge from both inside and outside. They might have to replace their knowledge from their collaborators so that upgradation of knowledge could occur continuously. However, poor management of knowledge and incompatibility between internal-external environmental factors for knowledge collection can lead towards serious competitive risks (Van den Hooff \& Van Weenen, 2004). This may partly be occurring because of lack on management interest or employees form the relevant source of knowledge or usage of knowledge. At time when these sorts of practices and inconsistencies might be recognized, firms could then gather knowledge for internal usage (Gold et al., 2001). Firms create knowledge basis gathering in sequence through a variety of external and internal sources. The research indicates that firms' innovation capabilities are subject to knowledge availability and dissemination (Alegre et al., 2011; Carneiro, 2000). Therefore, in view of above literature we hypothesize that:

$\mathrm{H}_{2}$ : Knowledge collection has positive and significant impact on innovation capacity of SMEs.

\section{Knowledge organizing}

Knowledge organizing involves knowledge processing activities to alter knowledge to a superior variety (O'dell \& Grayson, 1998). Further Lawson (2002) portrayed knowledge organizing as a strategy to knowledge evaluation on standard foundation, maintaining the latest knowledge, having instruments for integrating different sources, cross listening knowledge sorts, offering reaction to workers on their thoughts and knowledge. In fact, knowledge organizing is an important ingredient in knowledge management strategies and to that of innovation also (Chen \& Huang, 2007). Knowledge organizing 
revolves around four stages that are: acquisition, storage, distribution, and use of knowledge (Gonzalez \& Martins, 2017). In addition, acquisition and storage are ongoing procedure. Organizational knowledge is an asset that contributes significantly in attaining competitive advantage, and therefore needs clear and effective management and organization of knowledge (Wasko \& Faraj, 2005; Tata \& Prasad 2004). Rowley (2000), however, in this regard suggested the following procedures for organizing knowledge:

a) Knowledge requires to be systematized for communities.

b) In scheming tools to hold up organization regarding knowledge, commanding principle must be that of customer orientation and chief usage.

c) Networking offers communications that make easy efficient and effective admittance to documents and information (Rowley, 2000).

In view of above literature we hypothesize that:

$\boldsymbol{H}_{3}$ : Knowledge organizing has positive and significant impact on innovation capacity of SMEs.

\section{Knowledge storage}

Alavi (2000) asserted that creating knowledge and novel knowledge might not be sufficient and procedures should be required to amass needed knowledge along with to retrieve it when desirable. Secretarial memory involves knowledge be inherent with a variety of constituent sorts which might involve written certification, pre-arranged in sequence stored in electronic databases, codified knowledge obtain from employees skills could be stored in expert systems, recognized processes and practices of organization, along with tacit knowledge needed by individuals and network (Tan et al., 1998). Memory of organizations involves memory of employees (experiences, observation and actions of persons) in addition to shared interactions and knowledge (Park, 2006), organizational culture (Van den Hooff \& Van Weenen, 2004, Call, 2005), transformations, structure (formal roles of organizational), ecology (corporeal employment setting) and documentations of information (organization outside and inside) (Walsh \& Ungson, 1991). All organizations those are willing so that their organizational knowledge to be obliged to as a minimum have an immense command of fundamental processes of knowledge management. Knowledge storage, however, remained question of concern for many contemporary organizations particularly (Olivera, 2000).

The research is indicative of knowledge storage and innovation relationship and investigation suggested that knowledge storage can yield optimal benefits for organizations to gain and maintain competitive advantage (Sher \& Lee, 2004).

In addition, organizations must build up sanctuary technologies to bound accessibility of specific knowledge (Zack, McKeen \& Singh, 2009). Subsequent actions are noteworthy for shielding knowledge: knowledge fortification adjacent to unfortunate utilization or being escaped outside or inside of firm, imperfect convenience to certain knowledge sources by password expertise, identifying limited knowledge effortlessly; tacit knowledge fortification and a large amount significantly, conversing significance of 
knowledge fortification on an organizational level (Probast et al., 2000). Allameh et al., (2011) described that procedure of knowledge storage might have succeeding factors:

- An arrangement that permits scheme to express rapid and correct information.

- Policies, events or procedures classifications depend on erudition needs.

- Capability to present precise and clear information.

- An on instance, precise and accessible content

In view of above literature we hypothesize that:

$\boldsymbol{H}_{4}:$ Knowledge storage has positive and significant impact on innovation capacity of SMEs.

\section{Knowledge dissemination}

The technique of transmitting acquaintance to other employees who entail that knowledge in organization is called knowledge dissemination (Allameh et al, 2011). Previous researchers have found that knowledge could be utilized at numerous levels of firms, it must be shared and distributed within the organization (Bhatt, 2001; Darroch, \& McNaughton, 2002; Darroch, 2005). Alavi \& Leadner (2001) described dissemination of knowledge as method of knowledge transfer throughout firm. Knowledge dissemination practices could happen flanked by entities, organizations or groups exploiting at all sort or series of communication. Correspondingly, Gupta \& Govindarjan (2000) associated knowledge sharing to knowledge streams and hypothesized that knowledge sharing encompasses five constituents: worth of basis of knowledge, eagerness from resource to share knowledge, media prosperity of communiqué channel, readiness of beneficiary to obtain knowledge appropriately and absorptive capacity of beneficiary. Knowledge sharing is also described by Davenport and Prusak (1998) as a procedure of knowledge swap by groups and individuals. Written procedures include communications from individual for instance reports, bulletins, notes and also publications. Knowledge storage and dissemination have been considered as vital ingredient for innovation and competitive advantage. Therefore, on the basis of literature, we hypothesize that:

\section{$\boldsymbol{H}_{5}:$ Knowledge dissemination has positive and significant impact on innovation capacity of SMEs.}

\section{Knowledge application}

Focal point in KM is to construct and convince that offered knowledge is in accordance and is considered as significantly useful for the organization (Probst, Rub \& Rumhardt, 2000; McDermott, 1999). The valuable KA assists organizations to enhance their competence and decrease costs (Davenport \& Klahr, 1998). KA involves decision-making protection, action and problem solving applications that could at the end lead to creation of knowledge. Knowledge that is created requires be capturing, sharing, applying and consequently this cycle remains continue. Procedures of KM prop up procedures by which employees generate knowledge. In sequence technology bears KA in firms 
through exploiting a directorial practice (Gottschalk, 2008; Civi, 2010). The same as there existed difficulties in process of sharing of knowledge, there are obstructions under process of knowledge application (Mavondo, \& Farell, 2004). These troubles might emerge because of: firm sightlessness, panic of viewing tender summits or disbelieve in the direction of foreign knowledge. Schedule and uninteresting flow of matters and employments constructs it trickier for individuals to identify significance of novel information or design replace from associates regarding novel employment procedures. As a result, personnel will not anymore consider that novel practices can enhance performance and efficiency. The successful knowledge application is of paramount importance for the attainment of innovation objectives in highly volatile business environment (Probst et al., 2000). In view of above literature we can hypothesize that:

$\boldsymbol{H}_{6}:$ Knowledge application has positive and significant impact on innovation capacity of SMEs.

\section{Relationship between KM and innovation}

Innovation has been described as a vital element for growth (Volberda et al., 2014). Massa \& Testa (2004) described that firms might enlarge receivers that expand or take up external knowledge and this action is strappingly associated with capacity of innovation. Additionally, these investigators stated that all the way through benchmarking, firms might attain tacit and explicit knowledge from external basis. These external knowledge sources could be integrated with internal explicit and tacit knowledge of organization if acquaintance gap overcomes which could be crammed from novel acquisition of knowledge that will be obliging to boost up innovation. Ju et al., (2006) mentioned that with the intention of attaining competitive benefit, firms should become skilled from external sources. All the way through appropriate distribution and sharing of knowledge, firms could boost up innovation. Therefore, firms must extend these channels inside firm from which workers share knowledge with other workers. Plessis (2007) and Schelfhaudt \& Crittenden (2003) described that innovation is dependent on knowledge. Therefore, to boost up innovation, firms have to recognize capability of knowledge, and prosperity. Figure 1 illustrates the conceptual model of the study and relationships studied.

\section{Materials and methods}

The focal point of this empirical study was to recognize key procedures of knowledge management that influence innovation in SMEs' sector of AJ\&K. Current investigative study was a cross sectional study because data were collected one time only. Most business and management research fall into cross sectional category, however longitudinal and time lagged data are also preferred to avoid certain biases.

For the aim to collect the data, we have used criterion-based assortment. In the present research, we have only included those SMEs focusing on innovation and change by personally visiting SMEs. Participants were conveniently selected from SMEs' sector of AJ\&K for the data collection from different districts of AJ\&K. 


\section{IV}

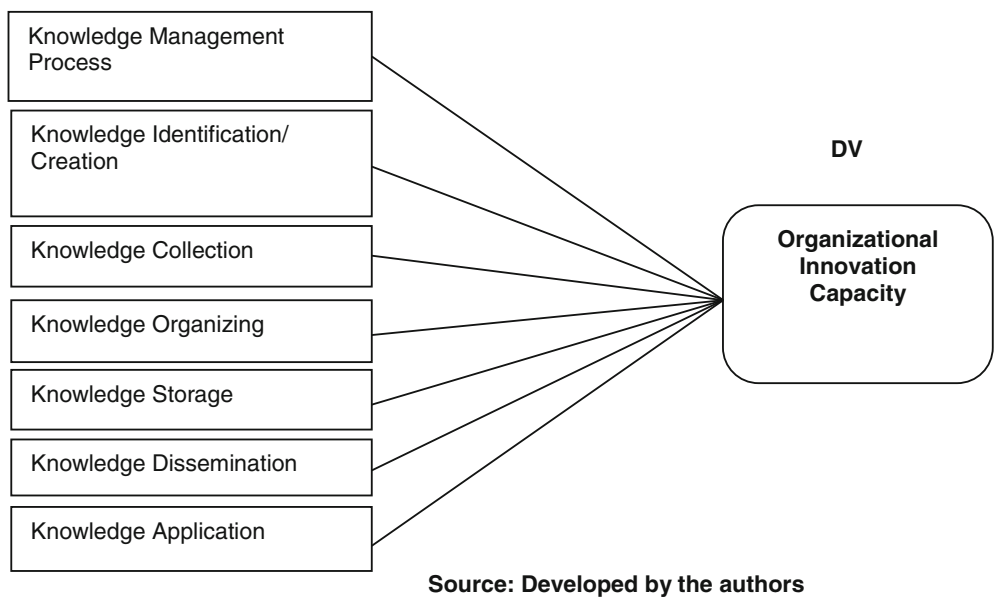

Fig. 1 Conceptual model

Data were collected through a self-administered questionnaire. A five point Likert scale was used for this purpose. As mentioned earlier, to address our research questions and achieve our research objectives, we have selected firms from AJ\&K only. The respondents were chosen from managerial sector i.e. owners, manager, operational manager, and marketing managers. Prior to visits, milieu information on investigative project was sent to all contestants for greater in sequence and as an orientation throughout filling of questionnaires. Questionnaires were dispensed to be completed by managers and owners of the SMEs' sector. A total of 212 questionnaires were distributed and from those 180 were received yielding $84.90 \%$ response rate.

\section{Research methodology}

It is understood that any research methodology has its own challenges and this research study is no exception. A number of challenges were faced. Among those faced was the response rate for the survey. Although response rate is a concern for most surveys, however ability to report on it reflects the quality of the survey. Thus, taking this stance, both unit and item non-response were faced. Item non-response was faced such that in some cases, some questionnaires were only answered half way while in other questionnaires some questions were not attempted. For item non-response for questions that were not attempted at all, the researcher considered such questions as unanswered and labeled them "non-response". On the other hand, unit response was more observed than item non-response, only one hundred and eighty (180) questionnaires were finally selected for further analysis (Table 1).

\section{Variables}

Mainly one variable along with different dimension has been used for the current study. Different dimensions of KM process were selected for the current study they are i.e. knowledge identification/creation, knowledge collection, knowledge organizing, knowledge sharing, knowledge dissemination and knowledge application. For the current 
Table 1 Constructs of all variables

\begin{tabular}{|c|c|}
\hline Knowledge Identification/Creation & $\begin{array}{l}\text { i. Recognizing accessible knowledge and ability both external and } \\
\text { internal to business organizations. } \\
\text { ii. Demanding to regulate knowledge and capabilities of employees } \\
\text { with necessary knowledge } \\
\text { iii. Encompassing procedure of acquiring and creating knowledge } \\
\text { from diverse foundations for instance customers, employees, } \\
\text { organizations and business partners. }\end{array}$ \\
\hline Knowledge Collection & $\begin{array}{l}\text { i. Gathering essential knowledge that is recognized from numerous } \\
\text { sources. } \\
\text { ii. Offering the leeway to inquire when there exists a require to } \\
\text { convinced knowledge } \\
\text { iii. Offering in sequence regarding what we know. }\end{array}$ \\
\hline Knowledge Organizing & $\begin{array}{l}\text { i. Comprising appropriate strategy to evaluate knowledge on a } \\
\text { customary foundation and maintain them advanced. } \\
\text { ii. Encompassing procedures for cross listing, filtering and integrating } \\
\text { diverse knowledge types. } \\
\text { iii. Offering feedback to workers regarding appropriate knowledge. }\end{array}$ \\
\hline Knowledge Storage & $\begin{array}{l}\text { i Exploiting repositories, databases and applications of information } \\
\text { technology to amass } \\
\text { ii. Knowledge for effortless contact by all workers. } \\
\text { iii. Exploiting numerous written mechanisms for instance manuals, } \\
\text { newsletter to accumulate knowledge }\end{array}$ \\
\hline Knowledge Dissemination & $\begin{array}{l}\text { i Comprising a sort of knowledge that is eagerly available to workers } \\
\text { who require it. } \\
\text { ii. Transferring out appropriate statements with suitable in sequence } \\
\text { to workers. } \\
\text { iii. Encompassing libraries, forums and resource centers to distribute } \\
\text { and display knowledge. }\end{array}$ \\
\hline Knowledge Application & $\begin{array}{l}\text { i. Encompassing diverse procedures for workers to further increase } \\
\text { their knowledge. } \\
\text { ii. Encompassing apparatus to guard knowledge internal and external } \\
\text { to firms. } \\
\text { iii. Applying knowledge to decisive spirited requires and rapidly } \\
\text { linked sources. }\end{array}$ \\
\hline Innovation & $\begin{array}{l}\text { i. Exploiting new ldeas. } \\
\text { ii. Looking for novel methods to doing things. } \\
\text { iii. Being inventive in use procedures. } \\
\text { iv. Marketing novel services and products commonly. }\end{array}$ \\
\hline
\end{tabular}

research study, we decided to use the methods that were used by Mehrabani \& Shajari (2012) to recognize impact of KM process on innovation capacity.

\section{Results and discussions}

The purpose of this study was to investigate the impact of KM on innovation in SMEs' sector of AJ\&K. The results of our study are discussed in the following section:

\section{Demographics attributes of respondents}

In order to identify demographics characteristics of respondents, frequency analysis was utilized. As milieu information is major part of research, so it is commonly asked from the respondents. Respondents were asked to name the organization (optional) they work for, record their age and designation in demographic section. In order to obtain a holistic summary of the data and to sum up quantitative information, descriptive statistic is very helpful. It permits the user to acquire the brief summary of whole quantitative data. Control variables are held constant during testing the relationship between 
Table 2 Frequency distribution of respondents

\begin{tabular}{ccc} 
& Frequency & Percent \\
\hline Public & 180 & 100.0 \\
\hline
\end{tabular}

dependent and independent variable and help in measuring this relationship accurately. In the current study, three control variables were used such as name, age and designations of the respondents (Table 2).

Table 3 reveals the age distribution of the respondents and shows that the age group $31-40$, yielded $37.2 \%$ response $(n=67)$. At the same time as respondents encompass age in range of $20-30(n=54)$ are $30.0 \%$ and the respondents having $41-50$ years of age are $22.3 \%,(n=40)$. The lowest frequency and percentage comes out in age range of $61-70$ are $2.2 \%(n=4)$.

Table 4 reveals the information regarding designation of the respondents. Almost $38.2 \%(n=69)$ respondents were owners, 27.2\% $(n=49)$ respondents were general managers and $18.3 \%(n=33)$ respondents were manager finance. Whereas 9.4\% $(n=17)$ were manager marketing and remaining $6.7 \%(n=12)$ were manufacturing managers.

\section{Reliability analysis}

Reliability of all measures was determined with the appropriate procedure suggested by Cronbach (1951). Nunnally \& Bernstein (1994) suggested that the Cronbach's alpha coefficient approximation for all measures must be .70 .

Table 5 shows that values of Cronbach's alpha for variables used in the model. Through this, we explored the degree to internal consistency and the reliability as well. The Cronbach's alpha for knowledge identification/ creation, Knowledge collection, Knowledge organizing, Knowledge sharing, Knowledge dissemination, Knowledge application and innovation is $(.837, .783, .687, .759, .851, .822, .818$ respectively). Therefore on the whole reliability of instrument is .794 .

Factor analysis were used on validated factors as a statistical tool to find the role of KM factors in increasing innovation capacity of SMEs in AJ\&K. The principal components analysis with Varimax rotation is applied to uncover the latent dimensions of a set of indicators in the survey. Principal components analysis helps to reduce a large number of indicators to a smaller number of factors. For each category in the survey, we used Likert type five-point scales: 5 being "Strongly Agree" and 1 being "strongly disagree," option. Table 6 reveals loading of Knowledge Identification/Creation factors, Knowledge Collection factors, Knowledge Organizing factors, Knowledge Storage factors, Knowledge Dissemination factors and Knowledge Application factors in

Table 3 Age distribution of respondents

\begin{tabular}{lll}
\hline & Frequency & Percent \\
\hline $20-30$ & 54 & 30.0 \\
$31-40$ & 67 & 37.2 \\
$41-50$ & 40 & 22.2 \\
$51-60$ & 15 & 8.3 \\
$61-70$ & 4 & 2.2 \\
Total & 180 & 100.0 \\
\hline
\end{tabular}


Table 4 Designation of respondents

\begin{tabular}{llc}
\hline & Frequency & Percent \\
\hline Owner & 49 & 27.2 \\
General Manager & 69 & 38.3 \\
Manger Finance & 33 & 18.3 \\
Manger Marketing & 17 & 9.4 \\
Manufacturing Manager & 12 & 6.7 \\
Total & 180 & 100.0 \\
\hline
\end{tabular}

determination of Innovation Capacity of SMEs in AJ\&K. The table also reflects loading for innovation. As it is obvious from the table, constructs used for knowledge identification, knowledge collection, knowledge organizing, knowledge storage, knowledge dissemination and knowledge application were the main factors among KM factors and have acceptable factor loadings as well. Innovation constructs also have acceptable factor loading values.

\section{Descriptive statistics}

Descriptive statistics offer a practical outline of security revisits when performing analytical and empirical analysis. The descriptive statistics of SMEs' sector is mentioned below (Table 7).

\section{Correlation}

In order to identify the correlation among the variables of research study, the Pearson product momentum correlation was used. The value of correlation for all variables is mentioned below. It indicates that there exists a positive and significant relationship among all variables.

\section{Regression}

By adding control variable in step 1 and relevant independent variable in step 2 step-wise linear regression was executed. In order to assess the change in independent variable the value of $\mathrm{R}$ square was used. To identify that which variable is used as a control variable between dependent and independent variable one way ANOVA was conducted.

Table 5 Reliability analysis

\begin{tabular}{llc}
\hline Constructs & No. of Items & Cronbach's a \\
\hline KI & 04 & .837 \\
KC & 04 & .783 \\
KO & 04 & .887 \\
KS & 04 & .759 \\
KD & 04 & .851 \\
KA & 04 & .822 \\
INV & 06 & .818 \\
Total & 30 & .794 \\
\hline KI knowledge Identification, KC Knowledge Creation, KO Knowledge Organizing, KS Knowledge Sharing, KD Knowledge \\
Dissemination, Ka Knowledge Application, INV Innovation
\end{tabular}


Table 6 Factor analysis

\begin{tabular}{|c|c|c|}
\hline Factors & Constructs & Loadings \\
\hline \multirow[t]{3}{*}{ Knowledge Identification } & $\begin{array}{l}\text { Recognizing accessible knowledge and ability both external } \\
\text { and internal to business organizations. }\end{array}$ & 0.685 \\
\hline & $\begin{array}{l}\text { Demanding to regulate knowledge and capabilities of } \\
\text { employees with necessary knowledge. }\end{array}$ & 0.713 \\
\hline & $\begin{array}{l}\text { Encompassing procedure of acquiring and creating } \\
\text { knowledge from diverse foundations for instance customers, } \\
\text { employees, organizations and business partners. }\end{array}$ & 0.753 \\
\hline \multirow[t]{3}{*}{ Knowledge Collection } & $\begin{array}{l}\text { Gathering essential knowledge that is recognized from } \\
\text { numerous sources. }\end{array}$ & 0.622 \\
\hline & $\begin{array}{l}\text { Offering the leeway to inquire when there exists a require to } \\
\text { convinced knowledge }\end{array}$ & 0.711 \\
\hline & Offering in sequence regarding what we know & 0.676 \\
\hline \multirow[t]{3}{*}{ Knowledge Organizing } & $\begin{array}{l}\text { Comprising appropriate strategy to evaluate knowledge on a } \\
\text { customary foundation and maintain them advanced. }\end{array}$ & 0.643 \\
\hline & $\begin{array}{l}\text { Encompassing procedures for cross listing, filtering and } \\
\text { integrating diverse knowledge types. }\end{array}$ & 0.721 \\
\hline & $\begin{array}{l}\text { Offering feedback to workers regarding appropriate } \\
\text { knowledge. }\end{array}$ & 0.812 \\
\hline \multirow[t]{3}{*}{ Knowledge Storage } & $\begin{array}{l}\text { Exploiting repositories, databases and applications of } \\
\text { information technology to accumulate. }\end{array}$ & 0.802 \\
\hline & Knowledge for effortless contact by all workers. & 0.738 \\
\hline & $\begin{array}{l}\text { Exploiting numerous written mechanisms for instance } \\
\text { manuals, newsletter to accumulate knowledge. }\end{array}$ & 0.799 \\
\hline \multirow[t]{3}{*}{ Knowledge Dissemination } & $\begin{array}{l}\text { Comprising a sort of knowledge that is eagerly available to } \\
\text { workers who require it. }\end{array}$ & 0.698 \\
\hline & $\begin{array}{l}\text { Transferring out appropriate statements with suitable in } \\
\text { sequence to workers. }\end{array}$ & 0.672 \\
\hline & $\begin{array}{l}\text { Encompassing libraries, forums and resource Centre to } \\
\text { distribute and display knowledge. }\end{array}$ & 0.688 \\
\hline \multirow[t]{3}{*}{ Knowledge Application } & $\begin{array}{l}\text { Encompassing diverse procedures for workers to further } \\
\text { increase their knowledge. }\end{array}$ & 0.732 \\
\hline & $\begin{array}{l}\text { Encompassing apparatus to guard knowledge interior and } \\
\text { exterior to firms. }\end{array}$ & 0.787 \\
\hline & $\begin{array}{l}\text { Appling knowledge to decisive spirited requires and rapidly } \\
\text { linked sources. }\end{array}$ & 0.766 \\
\hline \multirow[t]{4}{*}{ Innovation } & Exploiting new Ideas. & 0.658 \\
\hline & Looking for novel methods to doing passions. & 0.782 \\
\hline & Being inventive in using procedures. & 0.823 \\
\hline & Marketing novel services and products commonly. & 0.786 \\
\hline
\end{tabular}

Table 7 Descriptive statistics

\begin{tabular}{llllll}
\hline Variable & $\mathrm{N}$ & Minimum & Maximum & Mean & Std. Deviation \\
\hline KI & 180 & 1.00 & 5.00 & 3.5528 & 0.64925 \\
KC & 180 & 1.00 & 5.00 & 3.3417 & 0.64526 \\
KO & 180 & 1.00 & 5.00 & 3.5222 & 0.63450 \\
KS & 180 & 1.00 & 5.00 & 3.6861 & 0.55405 \\
KD & 180 & 1.00 & 5.00 & 3.5250 & 0.70117 \\
KA & 180 & 1.00 & 5.00 & 3.8278 & 0.46604 \\
INV & 180 & 1.00 & 5.00 & 3.8278 & 0.45797 \\
\hline
\end{tabular}


Table 8 Correlation among variables in public sector

\begin{tabular}{|c|c|c|c|c|c|c|}
\hline & 1 & 2 & 3 & 4 & 5 & 6 \\
\hline $\mathrm{KI}$ & 1 & & & & & \\
\hline KC & .064 & 1 & & & & \\
\hline $\mathrm{KO}$ & $.329^{b}$ & $.333^{b}$ & 1 & & & \\
\hline KS & $.429^{b}$ & -.201 & .112 & 1 & & \\
\hline $\mathrm{KD}$ & .119 & $.355^{b}$ & .183 & $.248^{\mathrm{a}}$ & 1 & \\
\hline KA & $.167^{\mathrm{a}}$ & .170 & $.262^{\mathrm{b}}$ & $.249^{b}$ & .159 & 1 \\
\hline INV & $.243^{b}$ & $.321^{b}$ & $.364^{b}$ & $.249^{b}$ & $.329^{b}$ & $.277^{\mathrm{b}}$ \\
\hline
\end{tabular}

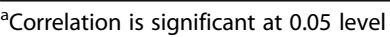

${ }^{b}$ Correlation is significant at 0.01 level

${ }^{\mathrm{C}}$ Correlation is significant at 0.001 level

$K I$ Knowledge Identification, KC Knowledge Creation, KO Knowledge Organizing, KS Knowledge Sharing, KD Knowledge

Dissemination, KA Knowledge Application, INV Innovation

\section{One-way ANOVA test}

For demographic variables, this test was executed and it was found that simply age has a noteworthy connection with dependent variable i.e. innovation in SMEs' sector as shown in Table 8 . The F value of age is 2.944 having significant level of 0.000 for SMEs.

\section{Step-wise linear regression analysis}

In step 1 of regression examination demographic variables, age was added as a control variable. In order to find out the variation in dependent variable i.e. innovation due to independent variable was entered in step 2.

$\mathrm{R}$ square value reveals that appropriate variation in innovation is because of independent variables for SMEs' sector. In order to explore overall strength of model F-statistics was executed. The values show that model possess significant overall strength for SMEs. On beta coefficient basis, the model depicts that increase in one unit of knowledge identification causes $23 \%$ of increase in innovation in SMEs sector and the value is significant. Similarly one unit increase in knowledge creation causes $21 \%$, knowledge organizing causes $25 \%$, knowledge storage causes $18 \%$, knowledge dissemination causes $37 \%$ and knowledge application causes 38\% variation in innovation. This shows that there exists a positive association between KM process and innovation in SMEs' sector. So, all hypotheses are accepted as mentioned in the following table.

From Table 9, it is revealed that there exists an encouraging and significant association between all steps of KM process (knowledge identification/creation, knowledge collection, knowledge organizing, knowledge storage, knowledge dissemination and knowledge application) and innovation in SMEs' sector of AJ\&K. In this sector there exists a constructive and significant impact of $\mathrm{KM}$ on innovation.

\section{Summary of results}

The judgment regarding hypothesis of current investigative study are expressed in below mentioned table (Table 10).

\section{Conclusions}

The modified version of Demarest (1997) model was used as a useful and representative model for studying KM usefulness for SMEs. In particular the key areas within the model were found to be representative of approaches to KM in SMEs sector, namely: 
Table 9 Regression of knowledge management process and innovation

\begin{tabular}{|c|c|c|c|c|c|}
\hline \multicolumn{6}{|c|}{ Dependent Variable: Innovation } \\
\hline Predictor & $R^{2}$ & $\Delta R^{2}$ & $\mathrm{~F}$ & Sig & B \\
\hline \multicolumn{6}{|l|}{ Step 1} \\
\hline \multicolumn{6}{|c|}{ Control Variable } \\
\hline \multicolumn{6}{|l|}{ Step 2} \\
\hline $\mathrm{KI}$ & .371 & .054 & 60.110 & .000 & $.233^{* * *}$ \\
\hline $\mathrm{KC}$ & .333 & .014 & 50.810 & .000 & $.213^{* * *}$ \\
\hline $\mathrm{KO}$ & .397 & .080 & 67.119 & .000 & $.259^{* * *}$ \\
\hline KS & .348 & .031 & 57.319 & .000 & $.189^{* *}$ \\
\hline $\mathrm{KD}$ & .438 & .081 & 68.382 & .000 & $.379^{* * *}$ \\
\hline$K A$ & .448 & .012 & 72.182 & .000 & $.389^{* * *}$ \\
\hline
\end{tabular}

${ }^{* *} p<.001,{ }^{* *} p<.01,{ }^{*} p<.05$, control variable for innovation: Age

$K I$ Knowledge Identification, KC Knowledge Collection, KO Knowledge Organizing, KS Knowledge Storage, KD Knowledge Dissemination, KA Knowledge Application, $N=180$

\section{Knowledge Creation \\ Knowledge Collection \\ Knowledge Organizing \\ Knowledge Storage \\ Knowledge Dissemination \\ Knowledge Application/Use}

In terms of knowledge creation and collection, it was found that the SMEs recognized the need for creation of both scientific and social knowledge if the benefits of the KM were realized. However, the SMEs sector appeared to be less advanced in this area, having a more mechanistic approach to knowledge creation and relying less on social interaction. These findings are consistent with the some previous studies (e.g. McAdam, 2001; Daneshfard \& Mohammad, 2010).

Knowledge organizing and storage were found to be highly dependent on employee interchange, employee interaction and mechanism of storage. The SMEs were found to be more dependent on people based knowledge organization and storage. The reason for this finding was the lack of resource for strategic business improvement planning

Table 10 Results summary

\begin{tabular}{|c|c|c|}
\hline & Hypothesis Statement & Results \\
\hline $\mathrm{H}_{1}$ & $\begin{array}{l}\text { Knowledge identification/creation has positive and significant impact on innovation } \\
\text { capacity of organization. }\end{array}$ & Accepted \\
\hline $\mathrm{H}_{2}$ & $\begin{array}{l}\text { Knowledge collection has positive and significant impact on innovation capacity of } \\
\text { organization. }\end{array}$ & Accepted \\
\hline $\mathrm{H}_{3}$ & $\begin{array}{l}\text { Knowledge organizing has positive and significant impact on innovation capacity of } \\
\text { organization. }\end{array}$ & Accepted \\
\hline $\mathrm{H}_{4}$ & $\begin{array}{l}\text { Knowledge storage has positive and significant impact on innovation capacity of } \\
\text { organization. }\end{array}$ & Accepted \\
\hline $\mathrm{H}_{5}$ & $\begin{array}{l}\text { Knowledge dissemination has positive and significant impact on innovation capacity } \\
\text { of organization. }\end{array}$ & Accepted \\
\hline $\mathrm{H}_{6}$ & $\begin{array}{l}\text { Knowledge application has positive and significant impact on innovation capacity of } \\
\text { organization. }\end{array}$ & Accepted \\
\hline
\end{tabular}


within SMEs. These findings are consistent with the some previous studies (Demarest, 1997; McAdam, 2001; Sadler-Smith et al., 1998; Wilkes \& Dale, 1998; Gray, 2006).

Approaches to knowledge dissemination as part of a KM system were found to be mainly ad-hoc. There was little use of the more sophisticated methods available. SMEs sector relied more on people based approaches as mentioned earlier to disseminate knowledge across the organization. These findings are consistent with the some previous studies (Demarest, 1997; McAdam, 2001; Sadler-Smith et al., 1998; Wilkes \& Dale, 1998; Sabherwal, \& Becerra-Fenandez, 2003).

The application of KM with in the SME studied was based mainly on reduced costs, and improved quality and efficiency. The SMEs sector responses were less, reflecting a current direct emphasis on market rather than business efficiency planning. These findings are consistent with the some previous studies (Demarest, 1997; McAdam, 2001; Sadler-Smith et al., 1998).

Finally, it can be concluded that SMEs have much to gain by developing effective KM systems. The indications are that these systems are being developed to some degree, although a much more systematic approach is needed. The SME sector needs to develop their understanding of KM further as a key business driver rather than as a resource-intensive additional initiative.

Nowadays, organizations because of ever changing environment and structure, lose adaptable responses. SMEs are required to innovate for sustainable competitive advantage (Barney, 1991). KM is proposed from organizational management role and organizational culture and also entity behavior. In an era where capacity of innovations as a competitive advantage is recognized to be connected to KM, substantial curiosity in accepting KM procedure persists to be inclination. Furthermore, KM procedure could affect innovation capacity in firms. A significant constituent of this considerate in numerous firms might be re-configuration of $\mathrm{KM}$ role in enhancing capacity of innovation, which requires to be examined by administrators.

The ultimate focus of the current research was to investigate $\mathrm{KM}$ impact on innovation in SMEs sector of AJ\&K. SMEs choice was depending on conviction that $\mathrm{KM}$ is noteworthy for business organizations, as a variety of sources of literature have designated. It must be illustrious that SMEs sector in Pakistan is mounting fast, donating a widespread variety of novel services and products. However, this sector in AJ\&K needs lot of attention.

Major giving of this research is that it might be an effort to see sights of KM environment in SMEs in AJ\&K. The model reveals that KM process can have a constructive and noteworthy impact on innovation in SMEs' sector of AJ\&K. After careful analysis, it is concluded that although KM has positive and significant impact in SMEs' sector. Moreover researchers can cover these issues in their investigative paper like superior sample size could be considered and additional KM practices might be exploited to explore role of KM and impact on innovation can be checked.

Our study revealed that knowledge identification/ creation, knowledge collection, knowledge organizing, knowledge storage, knowledge dissemination and knowledge application is applied in SMEs' sector to bring the innovation. The combination of all these can help SMEs to bring greater level of innovation in organization.

The researchers have highlighted a basic map of how SMEs manage knowledge by utilizing these KM processes; however we do need to understand that SMEs have lot of 
problems and challenges, specifically in AJ\&K. Future studies may focus on problems and challenges associated with KM adoption and implementation in SMEs. Comparatively, the research on KM and SMEs is rare as compared to such studies on large organizations. It is not factual to believe that SMEs adopt, implement and use KM in similar ways as larger organizations with the only difference being in magnitude or scale. The researchers believe that current study has opened up avenues for future research, by stressing some of the unique issues involved with KM processes at SMEs. Due to time and resource horizons present study was limited to a smaller sample of SMEs. Upcoming researchers are required to extend our findings, confirm them through a bigger sample, and even by adding some more variables.

\section{Abbreviations}

AJ\&K: Azad Jammu \& Kashmir; KM: Knowledge Management; SMEs: Small and Medium Enterprises

\section{Acknowledgements}

Authors acknowledge the participants of the study and their banks management for providing data. Authors also acknowledge the support of University of Kotli Azad Jammu \& Kashmir for allowing us to move to market for data collection during official working hours.

\section{Funding}

No specific funding for this research was provided by any funding agency. However, University of Kotli encouraged researchers to carry out this study and helped authors wherever, required.

\section{Availability of data and materials}

The datasets generated and/or analyzed during the current study are available and can be submitted if required.

\section{Authors' contributions}

IH Contributed in all aspects in this study. However, his main contribution was in designing this study and then writeup. IH has worked on the background studies of the topic and finalized theoretical framework/ research model for the current study. AQ contributed in all sections, parts and steps of this study. Specifically, in data gathering. AQ helped in data collection as she was in close contact with SMEs because of her professional engagements with SMEs sector. She also worked on literature review section. GM also contributed in various parts of this research. Mainly he contributed in performing statistical tests and analyzing the results of the study. GM has significantly contributed in data analysis in SPSS and did results interpretation also. AW also remained an important part of this study all the time. However, his main contribution was in having critical literature analysis and building up theoretical part and hypotheses. MAW worked on data analysis and also wrote discussion section for this paper. ZI has worked on proof reading the manuscripts, and improved research methodology for the current study. He has also worked on answering reviewers comments. Zl has worked on proof reading the manuscripts, and improved research methodology for the current study. He has also worked on answering reviewers comments. All authors read and approved the final manuscript.

\section{Competing interests}

The authors declare that they have no competing interests.

\section{Publisher's Note}

Springer Nature remains neutral with regard to jurisdictional claims in published maps and institutional affiliations.

\section{Author details}

${ }^{1}$ Faculty of Administrative Sciences Kotli, University of Kotli Azad Jammu \& Kashmir, Kotli, Pakistan. ${ }^{2}$ Department of Public Administration, Faculty of Administrative Sciences, University of Kotli Azad Jammu \& Kashmir, Kotli, Pakistan. ${ }^{3}$ Department of Business Administration, Faculty of Administrative Sciences, University of Kotli Azad Jammu \& Kashmir, Kotli, Pakistan. ${ }^{4}$ Department of Commerce, Faculty of Commerce, University of Kotli Azad Jammu \& Kashmir, Kotli, Pakistan.

Received: 12 February 2018 Accepted: 19 November 2018

Published online: 07 January 2019

\section{References}

Abtahi, H., \& Salavati, A. (2007). Knowledge management in the organization. Tehran. In Iran. Alavi, B. (2000). Human resource management information system. Tadbir Magazine, (I.M.O), 105.

Alavi, M., \& Leidner, D. E. (2001). Knowledge management and knowledge management system: Conceptual foundations and research issues. MIS Quartely, 25(1), 107-136.

Alegre, J., Sengupta, K., \& Lapiedra, R. (2011). Knowledge management and innovation performance in a high-tech SMES industry. International Small Business Journal available at: http://isb.sagepub.com/content/early/2011/10/11/ 0266242611417472 
Allameh, S. M., \& Zare, S. M. (2011). Examining the impact of KM enablers on knowledge management processes. Procedia Computer Science, 3, 1211-1223.

Argote, L., McEvily, B., \& Reagans, R. (2003). Managing knowledge in organizations: an integrative framework and review of emerging themes. Management Science, 49, 571-582.

Barney J. (1991). Firm resources and sustained competitive advantage. Journal of Management, 17, 99-120.

Beesley, L.G.A. \& Cooper, C. (2008), Defining knowledge management (KM) activities: towards consensus, Journal of Knowledge Management, 1(3), 48-62.

Bennett, R., \& Gabriel, H. (1999). Organisational factors and knowledge management within large marketing departments: an empirical study. Journal of Knowledge Management, 3(3), 212-225.

Bhatt, G. D. (2000). Organizing knowledge in the knowledge development cycle. Journal of knowledge management, $4(1), 15-26$.

Bhatt, G. D. (2001). Knowledge Management in Organizations: Examining the Interaction Between Technologeis, Techniques, and People. Journal of Knowledge Management, 5(1), 68-75.

Bonte, W. \& Keilbach, M. (2005), Concubinage or marriage? Informal and formal cooperation for innovation, International Journal of Industrial Organization, 23 (3/4): 279-302.

Call, D. (2005). Knowledge management- not rocket science. Journal of Knowledge management, 9(2), 19-30 https://doi.org/ $10.1108 / 13673270510590191$

Carneiro, A. (2000). How does knowledge management influence innovation and competitiveness? Journal of Knowledge Management, 4(2): 87-93.

Chen, C., \& Huang, J. (2007). Strategic human resource practices and innovation performance - the mediating role of knowledge management capacity. Journal of Business Research, 62(1), 104-114.

Chen, Y. M., Liu, H. H., \& Wu, H. Y. (2016). Reputation for toughness and anti-dumping rebuttals: competitive rivalry, perceived benefits, and stage of the product life cycle. Journal of Business Research, 69(6), 2145-2150.

Chilton, M. A., \& Bloodgood, J. M. (2010). Adaption-innovation theory and knowledge use in organizations. Management Decision, 48(8), 1159-1180

Civi, E. (2000). Knowledge management as a competitive asset: a review. Marketing Intelligence and Planning, 18, 166-174.

Cronbach, L. J. (1951). Coefficient alpha and the internal structure of tests. Psychometrika, 16(3), 297-334.

Damanpour, F., \& Aravind, D. (2012). Managerial innovation: conceptions, processes, and antecedents. Management and Organization Review, 8(2), 423-454.

Daneshfard, K. A., \& Mohammad, Z. (2010). The Effect of KM on Reinforcement of Competitive Ability of Advisory Engineering Companies. Journal of Bassirat in Management, 17(45), 21-38.

Darroch, J. (2005). Knowledge management. innovation and firm performance, Journal of Knowledge Management, 9(3), $101-$ 115.

Darroch, J., \& McNaughton, R. (2002). Examining the link between knowledge management practices and types of innovation. Journal of Intellectual Capital, 3(3), 210-222.

Davenport, T. H., \& Prusak, L. (1998). Working Knowledge, How Organizations Manage What They Know. Boston, MA: Harrard Business Process.

Davenport, T. H., \& Prusak, L. (2000). Working knowledge: How organizations manage that they know. New York: McGraw-Hill.

Demarest, M. (1997). Understanding knowledge management. Long Range Planning, 30, 374-384.

Dilk, C., Gleich, R., Wald, A., \& Motwani, J. (2008). State and development of innovation networks, Evidence from the European vehicle sector. Management Decision, 46(5), 691-701.

Dove R. (1999). Knowledge management, response ability, and the agile enterprise. Journal of Knowledge Management, 3(1), 18-35

Ferraris, A., Santoro, G., \& Dezi, L. (2017). How MNC's subsidiaries may improve their innovative performance? The role of external sources and knowledge management capabilities. Journal of Knowledge Management, 21(3), 540-552.

Gloet, M., \& Terziovski, M. (2004). Exploring the relationship between knowledge management practices and innovation performance. Journal of Manufacturing Technology Management, 15(5), 402-409.

Goh, A. (2005). Harnessing knowledge for innovation: an integrated management framework. Journal of Knowledge Management, 9(4), 6-18.

Gold, A. H., Malhotra, A., \& Segars, A. H. (2001). Knowledge management: An organizational capabilities perspective. Journal of Management Information System, 18(1), 185-214.

Gonzalez, R. V. D. \& Martins, M. F. (2017). Knowledge Management Process: a theoretical-conceptual research. Gestão \& Produção, 24(2), 248-265.

Gottschalk, P. (2008). IT in Knowledge Management. In M. E. Jennex (Ed.), Knowledge Management: Concepts, Methodologies, Tools, and Applications (pp. 452-467). New York: Information Science.

Gray, C. (2006). Absorptive capacity, knowledge management and innovation in entrepreneurial small firms. International Journal of Entrepreneurial Behaviour \& Research, 12(6), 345-360.

Greiner, M. E., Böhmann, T., \& Krcmar, H. (2007). A strategy for knowledge management. Journal of Knowledge Management, 11, 3-15.

Gupta, A., \& Govindarajan, V. (2000). Knowledge flows within multinational corporation. Strategic Management Journal, 21(4), 473-496.

Hayes, R., Pisano, G., Upton, D., \& Wheelwright, S. (2005). Operations, strategy and technology: pursuing the competitive edge. In United Kingdom: Lightning source UK Itd.

Hussain, I., Si, S., \& Ahmed, A. (2010). Knowledge management for SMEs in developing countries. Journal of Knowledge Management Practice, 11(2), 1-14.

Kim, Y., \& Lui, S. S. (2015). The impacts of external network and business group on innovation: do the types of innovation matter? Journal of Business Research, 68(9), 1964-1973.

Lawson, S. (2002). Knowledge management assessment instrument. Nova Southeastern University.

Lin, H. F., \& Lee, G. G. (2005). Impact of organizational learning and knowledge management factors on e-business adoption. Management Decision, 43(2), 171-188.

Massa, S., \& Testa, S. (2004). Innovation or imitation? Benchmarking: a knowledge-management process to innovate services. Benchmarking: An International Journal, 11(6), 610-620. 
Mavondo, F., \& Farell, M. (2004). Cultural orientation: Its relationship with market orientation. innovation and organization performance. Management Decision, 41(3), 241-249.

McAdam, R., \& Reid, R. (2001). SME and large organization perceptions of knowledge management: comparisons and contrasts. Journal of knowledge management, 5(3), 231-241.

McCampbell, A. S., Clare, L. M., \& Gitters, S. H. (1999). Knowledge management: the new challenge for the twenty-first century. Journal of Knowledge Management, 3, 172-179.

McDermott, R. (1999). Learning across teams: The role of communities of practice in teams. Knowledge Management Review, 7(3).

Mehrabani, S. E., \& Shajari, M. (2012). Knowledge management and innovation capacity. Journal of Management Research, 4(2), 164-177.

Nonaka, I., \& Takeuchi, H. (1995). The Knowledge-Creating Company. Oxford: Oxford University Press.

Nunnally, J. C., \& Bernstein, I. H. (1994). Psychometric Theory (McGraw-Hill Series in Psychology) (Vol. 3). New York: McGraw-Hill.

O'dell, C., \& Grayson, C. (1998). only we knew what we know: identification and transfer of internal best practices. California Management Review, 4 (3), 154-174.

Olivera, F. (2000). Memory systems in organizations: an empirical investigation of mechanisms for knowledge collection. storage and access. Journal of management studies, 37(6), 811-832.

Park, K. (2006). A review of the knowledge management model based on an empirical survey of Korean experts. Doctoral dissertation, University of Kyushu, Korea.

Plessis, M. (2007). The role of knowledge management in innovation. Journal of Knowledge Management, 11(4), 20-29.

Probst, G., Raub, S., \& Romhardt, K. (2000). Managing Knowledge: Building Blocks for Success. New York: Wiley.

Quintas, P., Lefrere, P., \& Jones, G. (1997). Knowledge management: a strategic agenda. Long Rage Planning, 30, 385-391.

Rowley, J. (2000). Knowledge organization for a new millennium: principles and processes. Journal of Knowledge Management, 4(3), 217-223.

Sabherwal, R., \& Becerra-Fenandez, I. (2003). An empirical study of the effect of knowledge management processes at individual, group. and organizational levels. Decision Science, 34(2), 225-260.

Sadler-Smith, E., Sargeant, A., \& Dawson, A. (1998). Higher level skills training and SMEs. International Small Business Journal, $16(2), 84-94$.

Saenz, Aramburu \& Rivera (2009). Knowledge sharing and innovation performance. Journal of Intellectual Capital. 10, 22-36. of Manpower, vol. 24, No. 5, pp. 501-516.

Schelfhaudt, K., \& Crittenden, V. L. (2003). Specialist or generalist: views from academia and industry. Journal of Business Research, 58, 946-954.

Scuotto, V., Del Giudice, M., Bresciani, S., \& Meissner, D. (2017). Knowledge driven preferences in informal inbound open innovation modes: an explorative view on small to medium enterprises. Journal of Knowledge Management, 21(3), 640-655.

Sher, P. J., \& Lee, V. C. (2004). Information technology as a facilitator for enhancing dynamic capabilities through knowledge management. Information \& management, 41(8), 933-945.

Soliman F. \& Spooner K. (2000). Strategies for implementing knowledge management: role of human resources management. Journal of Knowledge Management, 4, 337-345.

Tan, S., Teo, H., Tan, B., \& Wei, K. K. (1998). Developing a preliminary framework for knowledge management in organization. AlS Electronic Library (A/SeL). http://aisel.aisnet.org/amcis1998/211.

Tata, J., \& Prasad, S. (2004). Team Self-management, Organizational Structure, and Judgments of team effectiveness. Journal of Management Issues, 16(2), 248-265.

Tether, B. S., \& Tajar, A. (2008). The organisational-cooperation mode of innovation and its prominence amongst European service firms. Research Policy, 37(4), 720-739.

Van den Hooff, B., \& Van Weenen, F. d. (2004). Committed to Share: Commitment and CMC Use as Antecedents of Knowledge Sharing. Knowledge and Process Management, 11 (1), 13-12.

Volberda, H. W., Van Den Bosch, F. A., \& Mihalache, O. R. (2014). Advancing management innovation: Synthesizing processes, levels of analysis. and change agents. Organization Studies, 35(9), 1245-1264.

Vrontis, D., Thrassou, A., Santoro, G., \& Papa, A. (2017). Ambidexterity, external knowledge and performance in knowledgeintensive firms. The Journal of Technology Transfer, 42(2), 374-388.

Walsh, J. P., \& Ungson, G. R. (1991). Organizational memory. Academy of Management Review, 16(1), 57-91.

Wasko, M. M., \& Faraj, S. (2005). Why should I share? Examining social capital and knowledge contribution in electronic networks of practice. MIS quarterly, 29, 35-57.

Wiig, K. M. (1997a). Integrating intellectual capital and knowledge management. Long Range Planning, 30, 399-405.

Wiig, K. M. (1997b). Knowledge management: where did it come from and where will it go? Expert Systems with Application, $13,1-14$.

Wilkes, N., \& Dale, B. G. (1998). Attitudes to self-assessment and quality awards: A study in small and medium-sized companies. Total Quality Management, 9(8), 731-739.

Zack, M., McKeen, J., \& Singh, S. (2009). Knowledge management and organizational performance: an exploratory analysis. Journal of knowledge management, 13(6), 392-409. 